\title{
Diversity of repC plasmid-replication sequences in Rhizobium leguminosarum
}

\author{
Sarah L. Turner, ${ }^{1}$ Lionel Rigottier-Gois, ${ }^{2}$ Rowena S. Power, ${ }^{1} \dagger$ \\ Noëlle Amarger ${ }^{2}$ and J. Peter W. Young ${ }^{1}$
}

1 Department of Biology, University of York, PO Box 373 , York YO1 5 YW, UK

2 INRA Laboratoire de Microbiologie des Sols, 17 rue Sully, BV1540, 21034 Dijon-Cédex, France

\author{
Author for correspondence: J. Peter W. Young. Tel: +44 1904 432914. Fax: +44 1904432860. \\ e-mail: JPY1@york.ac.uk
}

\begin{abstract}
Homologues of the plasmid replicator gene repC were detected and characterized in a sample of Rhizobium leguminosarum strains. Conserved PCR primers were designed from published sequences of repC; they amplified a fragment of about $\mathbf{7 5 0}$ bp from 39 out of $\mathbf{4 1}$ strains tested, and also from several Sinorhizobium strains, including 5 . meliloti. Restriction endonuclease digestion showed that the PCR product from individual strains, though uniform in size, was often heterogeneous in sequence. PCR products from 24 field isolates of $R$. leguminosarum from France, Germany and the UK were cloned and partially sequenced from both ends. Phylogenies constructed from the 5' and ' 3' ends (200 bp each) were largely congruent and demonstrated four clearly defined groups plus several unique strains. Published Agrobacterium repC sequences fall within the phylogeny of $R$. leguminosarum sequences, though not within any of the four groups. Specific pairs of PCR primers were designed for each of the four groups; 29 out of 41 R. leguminosarum strains gave a PCR product of the expected size with more than one group-specific primer pair. We hypothesize that the sequence groups correspond to incompatibility groups of Rhizobium plasmids.
\end{abstract}

Keywords: Rbizobium leguminosarum plasmids, repC, compatibility, plasmid probes

\section{INTRODUCTION}

Large, low-copy-number plasmids are common in the Rhizobiaceae. These plasmids ( $>100 \mathrm{~kb}$ in size) often encode characteristics that are important taxonomic markers, e.g. the ability of agrobacteria to induce plant tumours and the ability of rhizobia to enter into nitrogenfixing symbioses with legumes. The plasmids in this group of bacteria appear to be related, since plasmids isolated from agrobacteria have been shown to replicate in rhizobia and vice versa, and incompatibility between replicons isolated from the different genera has been noted (Hynes et al., 1985; O'Connell et al., 1987; Mozo et al., 1990). Incompatible plasmids are not maintained within the same host cell under non-selective conditions; this is thought to be the result of shared replication, replication control and/or partition functions (Novick, 1987).

\footnotetext{
†resent address: Department of Life Sciences, University of Nottingham, University Park, Nottingham NG7 2RD, UK.

The EMBL database accession numbers for the rep $C$ sequences in this paper are 269840-Z69879.
}

A single plasmid is sufficient to confer symbiotic proficiency in Rhizobium leguminosarum strains (Martínez et al., 1987). However, the symbiotic plasmid (pSym) is generally only a minor component of the extra-chromosomal DNA of an $R$. leguminosarum strain. The majority of strains contain between one and six additional, distinct cryptic plasmids. A minority of non-pSym plasmids affect symbiotic proficiency, although the cause of these phenotypes is not fully understood (Hynes \& McGregor, 1990; Velázquez et al., 1995). The plasmid complement of $R$. leguminosarum strains is stable under laboratory and field conditions, implying that the plasmids contribute advantageously to cell maintenance and/or replication. Some $R$. leguminosarum plasmids are apparently important for cell survival since they cannot be completely cured (Hynes et al., 1989), or their removal results in a strain with significantly impaired growth rates (Hynes \& McGregor, 1990). The genetics that underpin the stable maintenance of multi-replicon genomes in $R$. leguminosarum have not been studied in detail. Plasmid transfer studies have revealed cryptic plasmids that are incompatible with some symbiotic plasmids (Brewin et al., 1982) and symbiotic plasmids that are compatible with other pSyms (Geniaux 
Table 1. Bacterial strains used

\begin{tabular}{|c|c|c|}
\hline Strains & Characteristics & Reference/source \\
\hline \multicolumn{3}{|l|}{ Escherichia coli } \\
\hline $\mathrm{DH} 5 \alpha$ & 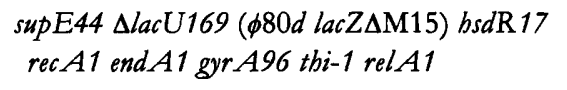 & Sambrook et al. (1989) \\
\hline \multicolumn{3}{|l|}{ Agrobacterium tumefaciens } \\
\hline & $\begin{array}{l}\text { /pTiB6S3; C58 chromosomal background } \\
\text { Rif }_{20}\end{array}$ & $\begin{array}{l}\text { J. Escuerdo, Leiden, The } \\
\text { Netherlands }\end{array}$ \\
\hline \multicolumn{3}{|l|}{ Rhizobium leguminosarum } \\
\hline 3841 & $\mathrm{Sm}^{\mathrm{R}}$ derivative of strain of $300 / \mathrm{pRL} 8 \mathrm{JI}$ & Johnston \& Beringer (1975) \\
\hline RSM2004 & Inoculant strain at UK release site (1987) & Hirsch \& Spokes (1994) \\
\hline $\begin{array}{l}\text { SC8, BA5, BA7, BA12, BA11, SC14, SA1, } \\
\text { BC1, SA10, BB18, SD13, SC12 and SD11 }\end{array}$ & Field isolates from Bretennières, France & \\
\hline $\begin{array}{l}\text { FIII-12, }-20,-36,-37,-38,-49,-50,-51,-52 \text {, } \\
-60,-61,-68,-69,-70,-71 \text { and }-72\end{array}$ & Field isolates from Schlüterhof, Germany & W. Lotz, Erlangen, Germany \\
\hline RES-1 to RES-10 & Field isolates from Harpenden, UK & P. Hirsch, Rothamsted, UK \\
\hline \multicolumn{3}{|l|}{ Sinorhizobium strains } \\
\hline \multicolumn{3}{|l|}{ S. meliloti } \\
\hline $\begin{array}{l}\text { A12, 14, 18, 19, 111, 212-216, 218, 219, } \\
312-316,318 \text { and } 319\end{array}$ & Field isolates from Granada, Spain & N. Toro, Granada, Spain \\
\hline \multicolumn{3}{|l|}{ S. teranga } \\
\hline ORS 1009 & Type strain & de Lajudie et al. (1994) \\
\hline \multicolumn{3}{|l|}{ S. saheli } \\
\hline ORS 609 & Type strain & de Lajudie et al. (1994) \\
\hline
\end{tabular}

\& Amarger, 1993). These observations are not unexpected since the only genes that are always associated with a plasmid belonging to one compatibility grouping are those involved in plasmid maintenance (Couturier et al., 1988).

We have recently described a replicator region isolated from the indigenous $R$. leguminosarum cryptic plasmid pRL8 JI (Turner \& Young, 1995). This replicator region shows significant organizational and sequence similarity to two replicator regions isolated previously from the Agrobacterium plasmids pRiA4b (Nishiguchi et al., 1987) and p'TiB6S3 (Tabata et al., 1989). These three replicator regions are each predicted to comprise three genes, $r e p A$, $B$, and $C$, with a conserved intergenic sequence (igs) located between the $r e p B$ and $C$ genes. The rep $C$ component codes for an essential replication function, whereas $\operatorname{rep} A$ and $B$ code for ancillary, stabilizing functions (Tabata et al., 1989). The predicted translation products of $\operatorname{rep} A$ and $B$ show amino acid sequence similarities to the partition proteins of the Escherichia coli phage P1 and plasmid RK2 (Williams \& Thomas, 1992).

The two cloned Agrobacterium plasmid replicator regions are known to be compatible (Tabata et al., 1989), even though they share significant amino acid sequence identity $(\approx 40-55 \%$ ) across each of the predicted RepA, B and C peptides. A similar level of sequence identity exists between these two replicator regions and the pRL8JI replicator. A fourth replicator region isolated from a Sinorbizobium meliloti strain has also been described. This replicator region, from $\mathrm{pRmeGR4a}$ (Mercado-Blanco \& Olivares, 1993), contains a repC homologue but neither $\operatorname{rep} A$ nor $r e p B$ homologues. The predicted pRmeGR4a RepC has limited ( $\approx 23 \%$ ) amino acid identity to the three other RepC proteins. The repC genes and their predicted peptide products show little similarity to any other DNA or protein sequences currently in the databases. This is in keeping with the observations of Kobayashi \& Bailey (1994), who investigated plasmid diversity in bacteria isolated from plant phyllospheres using the hybridized probes of Couturier et al. (1988). These probes, primarily designed to detect plasmids belonging to different incompatibility groups in clinical isolates, hybridized to few plasmids isolated from an agricultural environment.

An historical bias towards understanding the plasmid biology of clinically important bacteria has meant that plasmid systems in other bacteria have been overlooked. The potential use of microbes in agriculture, both in biological control and crop improvement, has stimulated interest in the plasmid biology of soil bacteria. This interest stems largely from the fact that plasmids are potential sources of horizontal gene transfer within soil populations. Gene transfer into, or out of, a genetically engineered microbe in the environment has serious implications for the use or design of such organisms.

A long-term aim of the present study is to assess the potential for, and frequency of, horizontal plasmid transfer within field populations of $R$. leguminosarum. The first requirement for such a study is a set of plasmidspecific probes that are representative of the plasmids present in soil populations. These can then be used to screen for plasmid transfer into tagged release strains. The presence of a unique family of plasmid replication 
sequences $(r e p C)$ in each of four cloned Rbizobiaceae replicator regions suggested that this gene might be a good target sequence for the design of PCR probes.

\section{METHODS}

Bacterial strains, plasmids and growth conditions. All bacterial strains used are listed in Table 1. R. leguminosarum field isolates represented the dominant genotypes present in each field site (W. Lotz \& P. Hirsch, personal communications).

E. coli DH5 $\alpha$ was grown at $37^{\circ} \mathrm{C}$ in $\mathrm{LB}$ and on $\mathrm{L}$ agar (Sambrook et al., 1989). When selection was required ampicillin was added to a final concentration of $100 \mu \mathrm{g} \mathrm{ml}^{-1}$. R. leguminosarum and Sinorbizobium strains were grown at $28^{\circ} \mathrm{C}$ in TY (Beringer, 1974); this medium was solidified with $1 \%(\mathrm{w} / \mathrm{v})$ agar as required. Plasmids pGEM-T (Promega) or pT\&-blueT-vector (Novagen) were used to clone PCR products.

General methods. Standard methods were used for the preparation and transformation of E. coli competent cells and for DNA manipulations and analyses (Sambrook et al., 1989). Plasmid DNA for sequencing and restriction analyses was prepared from $1.5 \mathrm{ml}$ of an overnight, $37^{\circ} \mathrm{C}$ E. coli culture using Wizard Mini-Prep Columns (Promega) or the Quiagen plasmid midi kit according to the manufacturers' instructions. Restriction endonucleases, Taq polymerase and T4 DNA ligase from Promega were used according to the manufacturer's instructions. PCR products were cleaned using Wizard PCRCleanup columns (Promega) prior to cloning.
Double-stranded plasmid DNAs were denatured with alkali prior to sequencing by the dideoxynucleotide chain-termination method using either $\left[\alpha^{35}\right.$ S $]$ thio-dATP (NEN-Du Pont), modified T7 polymerase (Sequenase; US Biochemical) and T7 and SP6 forward and reverse primers (Promega), or $\left[\alpha^{33} \mathrm{P}\right]$-dATP (Isotopchim), Pharmacia ${ }^{\text {T/ }}$ Sequencing Kit and 18-2 and 18-1 forward and reverse primers (Novagen).

PCR was performed on whole cells or on DNA purified according to the method of Laguerre et al. (1992), using the Taq polymerase from Promega supplied with $\mathrm{MgCl}_{2}$-free $10 \times$ buffer. Conditions for amplification with the general primer set were: $2 \mathrm{mM} \mathrm{MgCl}_{2}, 200 \mu \mathrm{M}$ dNTPs, 40 pmol each primer and $0.5 \mathrm{U}$ Taq per $50 \mu \mathrm{l}$ reaction. The amplification cycle used was: $97^{\circ} \mathrm{C}$ for $2 \mathrm{~min}$, followed by 35 cycles of: $48^{\circ} \mathrm{C}$ for $40 \mathrm{~s}, 72^{\circ} \mathrm{C}$ for $2 \mathrm{~min}$ and $93^{\circ} \mathrm{C}$ for $40 \mathrm{~s}$; the last cycle was followed by an additional annealing step and a final extension step of $10 \mathrm{~min}$. Conditions for group-specific PCR amplifications were: $1.5 \mathrm{mM}$ $\mathrm{MgCl}_{2}, 200 \mu \mathrm{M}$ dNTPs, 40 pmol of each primer and $0.5 \mathrm{U}$ Taq per $50 \mu \mathrm{l}$ reaction. Thermal cycling ( 25 cycles) was as above except that the annealing step was at $58^{\circ} \mathrm{C}$.

\section{RESULTS AND DISCUSSION}

\section{Most $R$. leguminosarum strains have repC-like sequences}

Peptide sequence comparisons of the pTiB6S3, pRiA4b and $p R L 8 J I$ RepCs identified regions of highly conserved amino acid residues (Fig. 1a). Investigation and com-

(a)

PRL8JI .METGYITTP FGRRPMTLAL VKRQVKTEQA IADGSVDKWR VFRHISDARS RLGLQDRALA VLNALLTFFP VAELSNERNL VVFPSNAQLS ARTNGIAGTT PRIA4b MMQTGSVTTP FGRRPMTLAL VRRQTALADI KQGKTADKWK VFRDASAAME LLGIQSNSLA VLDALLSFHP ETELRQEAQL IVFPSNAQLA LRAHGMAGAT PTIB6S .MQTHLSTTP FGRRPMTLGQ ISSQMSAKAV APDATANKWH VFQNIREARE LLGATDRSLA ILNALLTFHP ETTLTGDGEI IVWPSNEQLA ARANGMPATT MTTLLTP FGRPMTGQ ISSQMSAKAV APDATANKH VFQNIRERE LLGATDRSLA ILNALLTFHP ETTLTGDGEI IVWPSNEQLA ARANGMPATT 101 150 200

PRL8JI PRIA4b LRRHIAMLVE SGLIVRKDSA NGKRYARKDG AGQIERAFGF DLSPLLARSE ELAMMAQQVM ADRAAFRMAK ESLTICRRDV RKLITAAMEE GAEGDWQAVE PTIB6S LRRHLAVLVE CGLVIRRDSP NGKRFARKGR GGEIEQAYGF DLSPIVARAK EFRDMAEAIQ AEKKAFRVAK ERLTLLRRDI VKLIDAGIEE GVPGNWCGVQ Consensus LR-----LVE -G--IR-DS- NGKR-ARK-- -G-IE-A-GF -L-P--AR- - E----A-_-- A----FR--K - -LT--RRD- -KLI----EE ---G-W----

PRL8JI TCFVEIVGRF VRHPTLQDLI SSLDEMSLLH EEVSRMLEIK EETAKSDGNA IPDGCHIQNS NTESCHELE. PRSEKKQGEK SEPNKKTERK DEPEAFPLSM

PRIA4b EVYVELVGRI PRAPTLADVE SILEEMWMLQ EEIINRLEIR DNSENNSTNA AOSEOHIONS KPESVNELE. PRSEKEOGAK PSEIDRA.RS EPIKAFPLGM PTIB6S QVYQAIIGRL PRSAPRQLVE EICIGLHALY IEIRDVLESF AKTQIQDANE SHFGRHIQNS KPDSIPESEY GFGNKPEAGG TVEEFDNVRS LPKRELPLGI Consensus - 301

PRL8JI VLRACPEINA FGPGGSIGTW REMMSAAVTV RSMLGVSPSA YQEACEVMGQ AGAAIAIACI YQRGGHINSA GGYLRDLTGK GGRGEFSLGP MLFTQLRAN.

PRIA4b ILKACPTIGN YGPSGAVASW RDLMSAAVVV RSMLGVSPSA YQDACEAMGP ENAAAAMACI LERANFINSP GGYLRDLTRR SELGKFSLGP MIMALLKAS.

PTIB6S VLNACPSVLE LAQGGEIRHW RDFLATVELA RPMLGISQSA WREALDELGE QHAAITLAAI YQKADQIGSA GGYLRNLTDR ARDGKFSTWP MIMALLRAKL

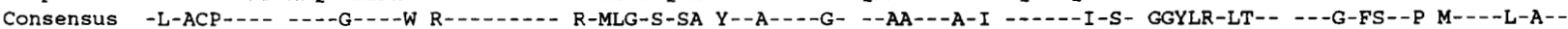

401

pRIA4b GQGTLREG* $\ldots \ldots \ldots \ldots \ldots \ldots$

pTIB6S DAQKVKADDR LPALNETADN GSGLRASDAL LRTLGKSRPK *

Consensus - -

(b)

\section{Forward primer}

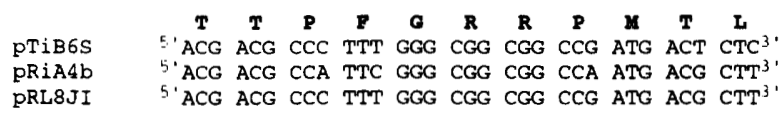

Primer RC1
Reverse Primer

H I $\quad \boldsymbol{Q}$ \& $\mathbf{S}$

$5^{\circ}$ CAC ATA CAG AAT TCA AAA CCA ${ }^{3}$

5 ' $\mathrm{CAC}$ ATA CAG AAT TCA AAA $\mathrm{CCC}^{3}$

5 ' CAC ATA CAG AAT TCA AAT ACC ${ }^{3}$

PRiA4b

pRL8JI

Primer RC3 "GTG TAT GTC TTA AGT TTT GG5"

Fig. 1. (a) RepC peptide sequence alignments. Two highly conserved regions that were investigated as possible general primer sites are indicated in bold in the consensus sequence. Arrows above the pRL8J sequence indicate the position and orientation of PCR primers: primers RC1 and RC3 are shown as solid arrows and group-specific primers as dashed arrows. (b) Nucleotide sequence alignments at the conserved amino acid sequences and primer sequences of RC1 and RC3. 
Table 2. $P C R$ amplification using the general repC primer set (RC1/3) or group-specific primer sets

\begin{tabular}{|c|c|c|c|c|c|c|}
\hline \multirow[t]{2}{*}{ Strains } & \multicolumn{5}{|c|}{ Primer sets used in PCR amplifications* } & \multirow{2}{*}{$\begin{array}{c}\text { Sequence group } \\
\text { of cloned PCR } \\
\text { product }\end{array}$} \\
\hline & RC1/3 & Group I & Group II & Group III & Group IV & \\
\hline \multicolumn{7}{|l|}{ R. leguminosarum } \\
\hline $\mathrm{SC} 8$ & + & - & - & + & + & III \\
\hline BA5 & + & - & - & + & + & III \\
\hline BA7 & + & + & + & + & + & I \\
\hline BA12 & + & + & - & + & + & I \\
\hline BA11 & + & - & + & + & + & II \\
\hline SC14 & + & + & + & + & + & II \\
\hline SA1 & + & - & - & + & + & III \\
\hline BC1 & + & + & + & - & + & I \\
\hline SA10 & + & + & + & - & + & \\
\hline BB18 & + & - & - & + & + & IV \\
\hline SD13 & + & - & - & + & + & III \\
\hline $\mathrm{SC} 12$ & + & - & - & + & - & \\
\hline SD11 & + & - & - & + & + & IV \\
\hline FIII-72 & + & + & + & + & + & \\
\hline FIII-69 & + & + & + & + & - & \\
\hline FIII-71 & + & + & + & + & + & II \\
\hline FIII-68 & + & + & + & - & + & II \\
\hline FIII-61 & + & + & - & + & + & \\
\hline FIII-60 & + & + & - & + & - & I \\
\hline FIII-51 & + & + & + & + & - & \\
\hline FIII-52 & + & + & + & + & + & \\
\hline FIII-50 & + & - & + & + & + & \\
\hline FIII-49 & + & - & + & + & + & \\
\hline FIII-36 & + & + & - & + & + & I \\
\hline FIII-38 & + & + & - & + & - & \\
\hline FIII-12 & + & - & - & - & + & \\
\hline FIII-20 & + & - & - & - & - & unique \\
\hline FIII-70 & + & + & + & + & + & I \\
\hline FIII-37 & + & + & + & - & + & \\
\hline RES-1 & + & - & - & + & - & unique \\
\hline RES-2 & - & - & - & + & - & \\
\hline RES-3 & - & - & - & - & - & \\
\hline RES-4 & + & - & - & + & - & II \\
\hline RES-5 & + & + & + & - & + & unique \\
\hline RES-6 & + & + & + & - & - & II \\
\hline RES-7 & + & - & - & + & - & III \\
\hline RES-8 & + & - & - & + & - & III \\
\hline RES-9 & + & - & - & + & - & \\
\hline RES-10 & + & - & - & - & + & \\
\hline 3841 & + & - & - & - & - & \\
\hline RSM2004 & + & - & - & + & - & \\
\hline S. teranga & + & - & - & - & ND & \\
\hline S. sabeli & + & - & - & - & ND & \\
\hline S. meliloti A14 & + & - & - & - & ND & \\
\hline A111 & + & - & - & - & ND & \\
\hline A212 & + & - & - & - & ND & \\
\hline A312 & + & - & - & - & ND & \\
\hline
\end{tabular}

+ , PCR product of expected size; - , no amplification. ND, Not done. 


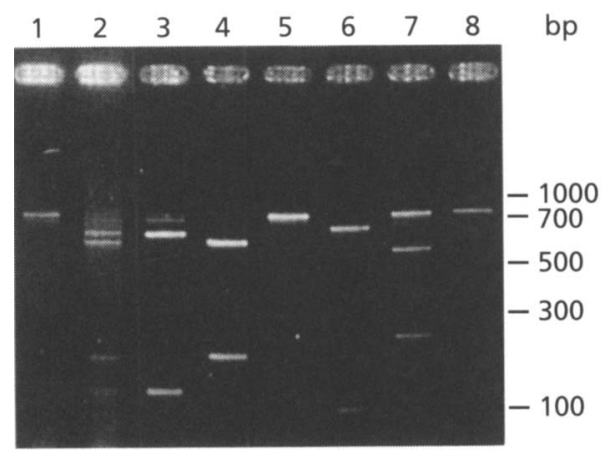

Fig. 2. Pstl restriction fragments of repC $P C R$ products amplified by the general primers RC1 and RC3. The PCR product amplified from $R$. leguminosarum strain FIII-71 is shown uncut (lane 1) and cut with Pstl (lane 2). Restriction patterns of products amplified from cloned repC sequences corresponding to groups I (BA12), II (BA11), III (SC8) and IV (RSM2004), are shown in lanes 3-6 respectively. The PCR product obtained from S. saheli is shown cut with Pstl (lane 7) and uncut (lane 8). parison of the corresponding DNA sequences identified conserved nucleotide sequences that might serve as suitable PCR primer sites. The two regions chosen as primer sites and the sequences of the resultant forward (RC1) and reverse (RC3) primers are shown in Fig. 1. PCR amplification using these primers with $R$. leguminosarum 3841, from which the pRL8JI replicator region was originally cloned, and Agrobacterium tumefaciens/pTiB6S3 generated products of the expected size $(\approx 750 \mathrm{bp})$ (data not shown).

PCR amplifications undertaken using the RC1/3 primer set with $39 \mathrm{R}$. leguminosarum field isolates from three field sites in Germany (16 strains), France (13 strains) and the UK (10 strains) gave amplification products with 37 of the 39 strains screened (Table 2). Although the PCR annealing temperature used $\left(48^{\circ} \mathrm{C}\right)$ is relatively low, only products of the expected size were seen following agarose gel electrophoresis (Fig. 2, lane 1), suggesting that the primers were amplifying specific sequences and not priming randomly. In addition, amplification using this primer set was obtained with R. leguminosarum strain RSM2004, which has selectable markers to enable it to be easily (a)

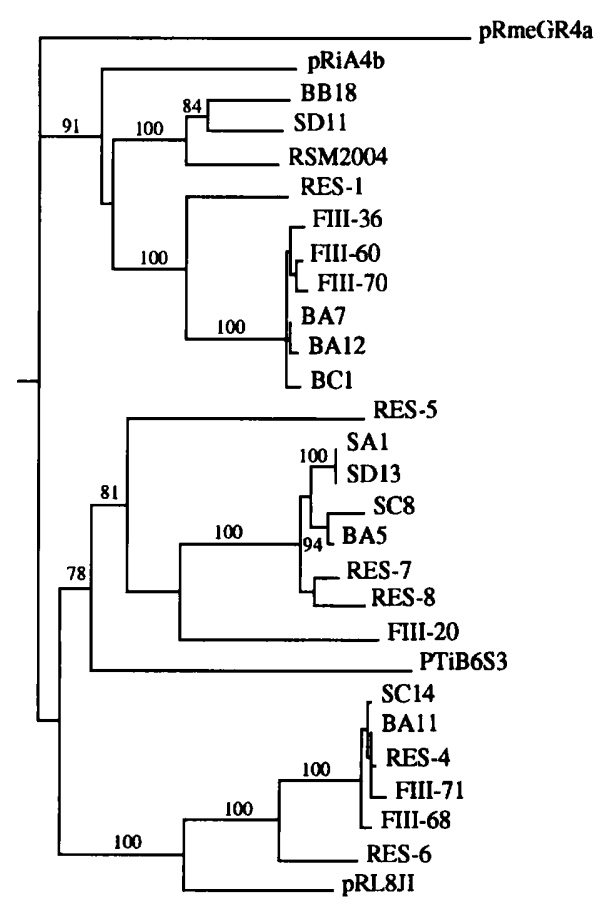

(b) pRmeGR4a

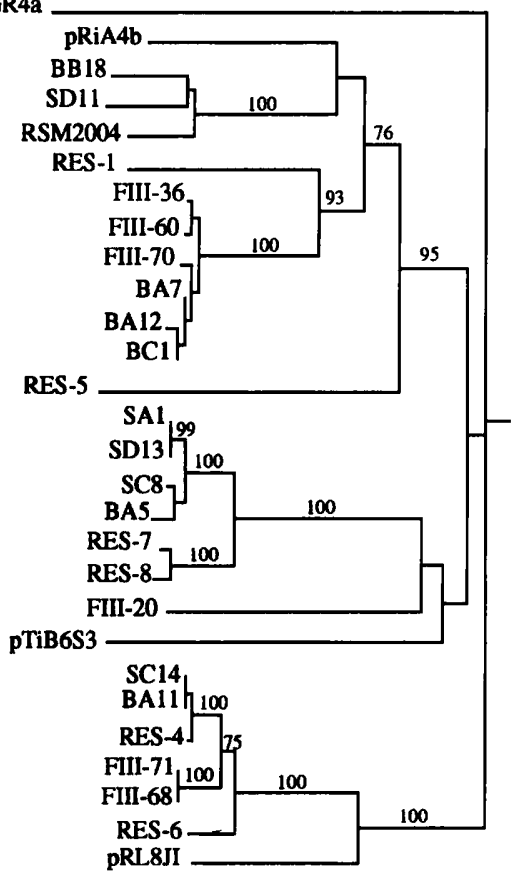

$10 \%$ divergence

Fig. 3. Phylogenetic relationships of partial repC sequences obtained from $R$. leguminosarum field isolates. (a) Relationships derived from the $200 \mathrm{bp}$ immediately following the RC1 primer site of the cloned DNAs. (b) Relationships derived from the $200 \mathrm{bp}$ immediately preceding the RC3 primer site. Neighbour-joining trees (Saitou \& Nei, 1987) were rooted using pRmeGR4a as the outgroup, and the percentage of bootstrap trials supporting a branch is shown when this exceeded $75 \%$ and the branch length exceeded $1 \%$. Four major groups of sequences, each amplified by group-specific primers, are indicated by roman numerals and by the shaded areas. Homologous published repC sequences are also included: pRmeGR4a from S. meliloti (Mercado-Blanco \& Olivares, 1993), pRiA4b from Agrobacterium rhizogenes (Nishiguchi et al., 1987), pTiB6S3 from A. tumefaciens (Tabata et al., 1989) and pRL8I from R. leguminosarum (Turner \& Young, 1995). 
recovered from soil and had previously been used as an inoculant at the UK field site.

\section{Most $R$. leguminosarum strains have more than one repC-like sequence}

Sequences that can be amplified by the RC1/3 primer set are common in $R$. leguminosarum strains isolated from each of the three field sites. This, combined with the fact that $R$. leguminosarum strains usually carry several compatible replicons, suggested that multiple, related $r e p C$ sequences could be being amplified from single strains during PCR. Analysis of the PCR products using a range of restriction enzymes (EcoRI, PstI, AluI, MspI, HinfI and HaeIII) gave complex banding patterns on gel electrophoresis. The presence of multiple bands of various intensities with all restriction enzymes indicated that several different $r e p C$ sequences had been amplified from a significant number $(>50 \%)$ of strains. An example is shown in Fig. 2 (lane 2). Furthermore, the pRL8JI $r e p C$ PCR product hybridized, at low stringency, with more than one plasmid in each of several field isolates (data not shown). Similar observations have been made by Murillo \& Keen (1994) for Pseudomonas syringae, in which compatible plasmids have cross-hybridizing replication segments.

\section{$R$. leguminosarum repC sequences form several divergent groups}

Since the PCR products were often heterogeneous, direct sequencing was not feasible. PCR products were purified and cloned prior to sequencing: PCR products were successfully cloned from eleven French, six German and six UK field isolates, and RSM2004 (see Table 2). The first and last $220 \mathrm{bp}$ of sequence of one clone of each of these strains was determined. The sequence data obtained included both the RC1 and RC3 primer sequences; these were used to align sequences but were ignored in subsequent statistical analyses.

Fig. 3 shows phylogenetic trees derived by the neighbourjoining method from the partial sequence data obtained. The two dendrograms represent the first $200 \mathrm{bp}$ (Fig. 3a) and the last $200 \mathrm{bp}$ (Fig. $3 \mathrm{~b}$ ) of the PCR products. The overall appearance of the two dendrograms is very similar and many branches are strongly supported by bootstrap analysis in both. Most of the field isolate sequences cluster into four tight groups, designated I, II, III and IV: sequences from strains BA7, BA12, BC1, FIII-36, FIII-60 and FIII-70 comprising group I: BA11, SC14, FIII-68, FIII-71, RES-4 and RES-6 comprising group II; SA1, SD13, SC8, BA5, RES-7 and RES-8 comprising group III, and BB18, SD11 and RSM2004 forming a more divergent but strongly linked fourth (IV) group. The pRL8JI sequences are distinct from but distantly related to the group II sequences and RES-1 sequences are similarly related to group I. The FIII-20 sequences show only relatively weak linkage with group III. The previously described sequences from the Agrobacterium plasmids $\mathrm{pRiA} 4 \mathrm{~b}$ and $\mathrm{p}$ TiB6S3 fall within the tree of $\mathrm{R}$. leguminosarum sequences, but are not clearly related to

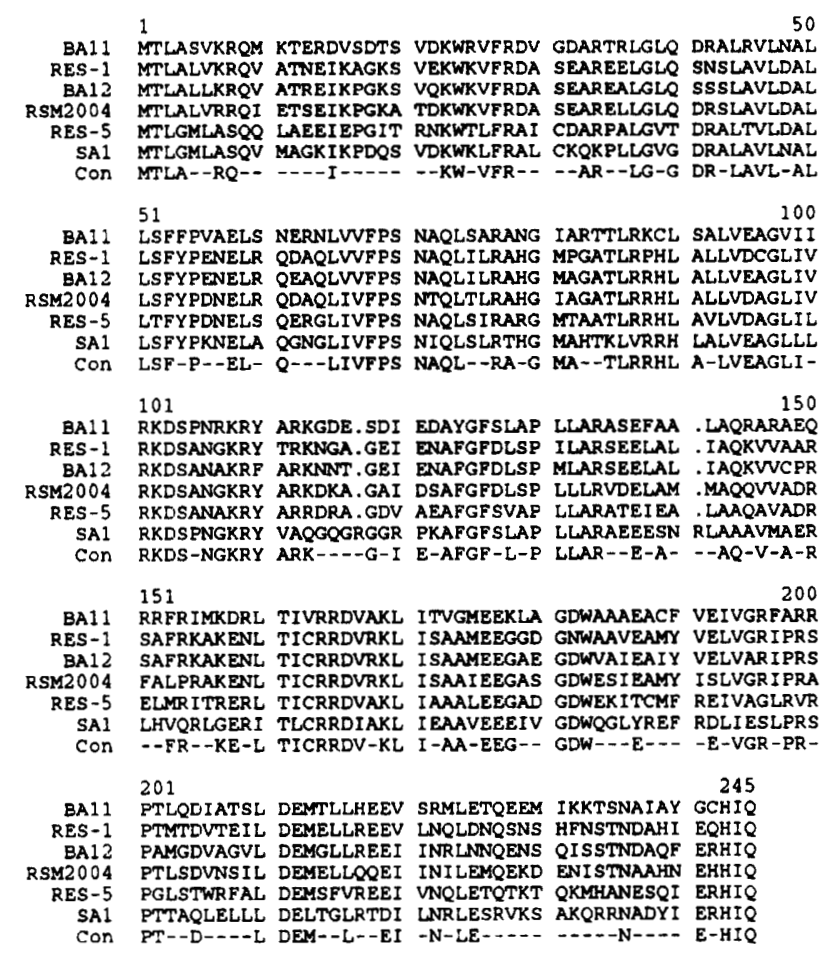

Fig. 4. An alignment of the partial peptides predicted from the repC sequences cloned from $R$. leguminosarum field isolates BA11, RES-1, BA12, RSM2004, SA1 and RES-5. The consensus (Con) shows amino acids shared by at least six of the nine known RepC sequences (i.e. these plus the pRL8JI, pTiB6S3 and pRiA4b sequences shown in Fig. 1).

particular groups. It is striking that the diversity of $r e p C$ sequences in $R$. leguminosarum is so great as to encompass sequences from another genus.

\section{The phylogenetic position of the RES-5 repC sequence is ambiguous}

In general, there is remarkable agreement between the phylogenies of the two parts of the repC sequence (Fig. 3). The only significant discrepancy is in the position of RES5: the $5^{\prime}$ sequence (Fig. $3 \mathrm{a}$ ) is associated with group III sequences, whereas the $3^{\prime}$ sequence (Fig. $3 \mathrm{~b}$ ) shows strong linkage with groups I and IV. These associations suggest that the RES-5 sequence could have arisen from a recombination event. The complete sequences of cloned PCR fragments representative of each of the groups I (BA12), II (BA11), III (SA1) and IV (RSM2004), and strains RES- 1 and RES-5 were determined (one strand only). Each of the six sequences would be predicted to be part of an open reading frame (Fig. 4). The in-frame translation products show significant amino acid similarity to the corresponding portion of the RepC sequences identified for $\mathrm{pRL} 8 \mathrm{JI}$ and the Agrobacterium plasmids pTiB6S3 and pRiA4b. There is no clearly defined point in Fig. 4 at which the RES-5 sequence switches from having greater similarity to SA1 (group III) to having greater similarity to BA12 or RSM2004 (groups I and IV respectively), but the RES-5 sequence is so divergent 


\begin{tabular}{|c|c|c|}
\hline $\begin{array}{c}\text { Group/ } \\
\text { strain } \\
\text { designation }\end{array}$ & Forward primer site & Reverse primer site \\
\hline pRmeGR4a & $\begin{array}{l}85 \\
\text { TCGGAACCGT GACGCGTGCC }\end{array}$ & $\begin{array}{lr}642 & 660 \\
\text { GCGGGCAACG GCTCTTCTGG }\end{array}$ \\
\hline pRiA4b & TCAAACAAGG CAAGACAGCG & CTTGCTGATG TAGAGTCAAT \\
\hline $\begin{array}{l}\text { BB18 } \\
\text { SD11 }\end{array}$ & $\begin{array}{l}\text { TTAAGCCAGG CAAGACEGCG } \\
\text { TTAAGCCOGG CAAGACAGCG }\end{array}$ & $\begin{array}{l}\text { CTCAGTGATG TGAATPCAAT } \\
\text { CTCबGTGATG TGAATTCAAT }\end{array}$ \\
\hline RSM2004 & TCAAACCAGG TAAGGCGACG & CTTAGTGACG TGAATTCAAT \\
\hline RES-1 & TCAAGGCCGG CAAATCGGTC & ATGACAGACG TCACAGAAAT \\
\hline group I & TCAAGCCGGG AAAATCGGTC & ATGGGAGACG TAGCGGGCGT \\
\hline RES-5 & TCGAACCTGG AATTACCCGG & ATTGAGGACC TGGCGATTTG \\
\hline$\underset{\text { III }}{\text { group }}$ & TCAAGCCGGA TCAGTCGGTC & ACAGCGCAGC TTGAACTGTT \\
\hline FIII-20 & TCGACCCGGC CAATCTATCG & GCCGAGCAGG TCGCCACCGC \\
\hline pTiB6s & TGGCGCCTGA CGCTACCGCA & AGACAGCTTG TGGAGGAGAT \\
\hline$\underset{\text { II }}{\text { group }}$ & ATGTCTCCGA CACCTCGGTA & TTACAAGACA TCGCAACGAG \\
\hline PRLEJI & CAATAGCGGC TGGCTCGGTC & CTCCAGGACC TGATTTCGAG \\
\hline
\end{tabular}

Fig. 5. Sequence alignments of the target sites for groupspecific forward and reverse primers. The numbers above each column refer to the nucleotide position in the $\mathrm{pRL8J}$ repC coding sequence. Group IV is represented by strains BB18 and SD11; the group IV primers were made with mixed nucleotides at the sites shown in bold.

from all these sequences that the site of such a recombination event would be hard to identify.

\section{The four repC sequence groups are widespread in $R$. leguminosarum field populations}

Sequence comparison of all 27 pairs of partial sequences enabled the design of group-specific PCR primers to amplify $r e p C$ sequences corresponding to each of the four main groups (I-IV) identified from phylogenetic analysis (Fig. 5). To facilitate the longer-term aims of this research (an assessment of plasmid transfer in soil populations of $R$. leguminosarum) one requirement for specific primers is that they should not amplify $r e p C$ sequences present in tagged release strains. Since RSM2004 is such a strain, the group IV primers were designed so that they would not amplify the $r e p C$ sequence isolated from this strain. All group-specific primer sequences correspond to the same two 20 bp regions of the $r e p C$ partial sequences (dashed arrows in Fig. 1). All the cloned sequences were amplified only by the corresponding group-specific primer pair, except that the RSM2004 cloned sequence was not amplified by any of them.

Table 2 summarizes results from PCR amplifications using these primer sets on the $39 \mathrm{R}$. leguminosarum field isolates. Amplification products were often obtained for more than one primer set from one strain, e.g. BA7 gave a positive result with all four primer sets. These results agree with the restriction enzyme analyses, which strongly suggested that multiple rep$p$-like sequences are present in a substantial proportion of the $R$. leguminosarum field isolates screened.

Homologous $\operatorname{rep} C$ sequences were not universally amplified by the general primer pair. For example, RES- 2 did not generate a PCR product with the general primer set, but did with the group III-specific primer set (Table 2). This presumably reflects sequence divergence at the general primer sites in this strain, since group III sequences were amplified and cloned from other strains (e.g. SC8 and RES-8). Group III and IV sequences were only cloned from strains that did not contain group I or group II sequences, suggesting that the group I and II rep $C$ sequences may match the general primers more closely than do the group III and IV sequences, and are consequently amplified more efficiently. This interpretation is supported by the relative intensities of the bands in Fig. 2: the restriction fragments corresponding to groups I and II are the strongest and those corresponding to groups III + IV restriction fragments are relatively weak.

No amplification products were obtained from strain RES-3 using any of the primer sets. This does not, of course, mean that the plasmids of this strain do not have $r e p C$ genes. In view of the high level of sequence diversity that we have documented, it is very likely that in this and other strains there are $\operatorname{rep} C$ genes that have diverged too much to amplify with any of the limited number of primers that we have used so far.

\section{Sinorhizobium strains also have repC-like sequences}

PCR using the RC1/3 primer set was used to assess whether related sequences are present in other species of rhizobia, including a number of $S$. meliloti strains isolated from a field site in Spain and type strains of $S$. sabeli and $S$. teranga, originally isolated from Senegal. Amplification products were generated in 18 out of $21 \mathrm{~S}$. meliloti strains and with both the $S$. sabeli and $S$. teranga strains. Again restriction enzyme analysis suggested that the PCR products represented heterogeneous mixtures of related sequences in many of the strains tested (Fig. 2, lane 7). However, when six Sinorbizobium strains were tested with the group I, II or III primer sets they did not generate amplification products. Thus the $r p C$ sequences present in Sinorbizobium strains appear to belong to groups other than I, II or III, which were the dominant repC classes amplified and cloned from $R$. leguminosarum strains.

\section{Wider implications}

The genetic diversity of the $\operatorname{rep} C$ sequences from $R$. leguminosarum is so great that some sequences are as different from each other as they are from the published sequences from Agrobacterium plasmids. This, together with the finding of related sequences in Sinorbizobium, suggest that the range of $r e p C$ sequences that we have described is not specific to $R$. leguminosarum, but may be characteristic of the whole branch of the alpha proteobacteria that includes these genera. In view of the high level of sequence divergence, it is possible that different $r e p C$ groups were already present in the common ancestor of this branch. However, it is also likely that considerable plasmid transfer has occurred subsequently, since conjugative plasmid transfer between these genera has been demonstrated experimentally (Martínez et al., 1987), and 
certain Rbizobium and Agrobacterium plasmids are incompatible with each other and therefore presumably closely related (Hynes et al., 1985; O'Connell et al., 1987; Mozo et al., 1990). We are currently surveying a wide range of related species to ascertain the distribution of the $r e p C$ groups that we have already identified.

We think it is likely that the $r e p C$ groups correspond to plasmid incompatibility groups, though there is as yet no direct evidence for this interpretation. In the Agrobacterium plasmids, the $\operatorname{rep} C$ gene encodes an essential replication function (Tabata et al., 1989) so it could plausibly be a determinant of incompatibility. The plasmids $\mathrm{pTiB} 6 \mathrm{S3}$ and $\mathrm{pRiA4b}$ are compatible, and the divergence between their rep $C$ sequences is comparable to that among the four groups that we have identified, suggesting that this level of divergence is sufficient (and may perhaps be necessary) to allow compatibility. Further studies are clearly needed to examine the possible role of $r e p C$ in plasmid incompatibility and to assess the functional significance of the sequence diversity. In addition, the $\operatorname{rep} A$ and $r e p B$ genes are adjacent to $r e p C$ in the Agrobacterium plasmids and in pRL8JI, though as yet we have no information for the other $R$. leguminosarum plasmids. The $r e p A$ and $r e p B$ genes have distant homologues in the partition functions of IncP plasmids and phage P1 (Williams \& Thomas, 1992), and are also likely to affect compatibility. If $r e p C$ is, or is closely linked to, the major determinant of plasmid incompatibility, then the sequences and primers that we have developed may form the basis for a general scheme for typing plasmids in this group of the alpha proteobacteria.

The primers will also be useful tools for studies of plasmid transfer in the field, which is of interest in the context of risk assessment for the release of genetically modified bacteria. One approach that we are pursuing is to monitor the acquisition of plasmids from the indigenous population by a marked release strain that initially lacks some or all of the $\operatorname{rep} C$ sequences that our primers recognize. More generally, a better understanding of the relationships, origins, host ranges and other properties of indigenous bacterial plasmids will have wide-ranging implications for the development of safe and effective microbial biotechnology.

\section{ACKNOWLEDGEMENTS}

This work was funded by the EU as part of BIOTECH contract BIO2-CT92-370. We thank Dr Jim Brannigan for PCR primer preparation, Kaisa Haukka for providing $S$. teranga and $S$. sabeli DNA, and those listed in Table 1 for providing strains.

\section{REFERENCES}

Beringer, J. E. (1974). R factor transfer in Rbizobium leguminosarum. $J$ Gen Microbiol 84, 188-198.

Brewin, N. J., Wood, E. A., Johnston, A. W. B., Dibb, N. J. \& Hombrecher, G. (1982). Recombinant nodulation plasmids in Rhizobium leguminosarum. J Gen Microbiol 128, 1817-1827.

Couturier, M., Bex, F., Bergquist, P. L. \& Maas, W. K. (1988). Identification and classification of bacterial plasmids. Microbiol Rev 52, 375-395.
Geniaux, E. \& Amarger, N. (1993). Diversity and stability of plasmid transfer in isolates from a single field population of Rhizobium leguminosarum bv. viciae. FEMS Microbiol Ecol 102, 251-260.

Hirsch, P. R. \& Spokes, J. D. (1994). Survival and dispersion of genetically-modified Rhizobia in the field and genetic interactions with native strains. FEMS Microbiol Ecol 15, 147-159.

Hynes, M. F. \& McGregor, N. F. (1990). Two plasmids other than the nodulation plasmid are necessary for formation of nitrogenfixing nodules by Rbizobium leguminosarum. Mol Microbiol 4, 567-574.

Hynes, M. F., Simon, R. \& Puhler, A. (1985). The development of plasmid-free strains of Agrobacterium tumefaciens by using incompatibility with a Rbizobium meliloti plasmid to eliminate pAtC58. Plasmid 13, 99-105.

Hynes, M. F., Quandt, J., O’Connell, M. P. \& Puhler, A. (1989). Direct selection for curing and deletion of Rhizobium plasmids using transposons carrying the Bacillus subtilis sacB gene. Gene $\mathbf{7 8}$, 111-120.

Johnston, A. W. B. \& Beringer, J. E. (1975). Identification of the Rbizobium strains in pea root nodules using genetic markers. $J$ Gen Microbiol 87, 343-350.

Kobayashi, N. \& Bailey, M. J. (1994). Plasmids isolated from the sugar beet phyllosphere show little or no homology to molecular probes currently available for plasmid typing. Microbiology 140, 289-296.

Laguerre, G., Mazurier, S. I. \& Amarger, N. (1992). Plasmid profiles and restriction length polymorphism of Rbizobium leguminosarum bv. viciae in field populations. FEMS Microbiol Ecol 101, 17-26.

de Lajudie, P., Willems, A., Pot, B., Dewettinck, D., Maestrojuan, G., Neyra, M., Collins, M. D., Dreyfus, B., Kersters, K. \& Gillis, M. (1994). Polyphasic taxonomy of rhizobia: emendation of the genus Sinorbizobium and description of Sinorbizobium meliloti comb. nov., Sinorbizobium sabeli sp. nov., and Sinorbizobium teranga sp. nov. Int J Syst Bacteriol 44, 715-733.

Martínez, E., Palacios, R. \& Sanchez, F. (1987). Nitrogen fixing nodules induced by Agrobacterium tumefaciens harboring Rbizobium phaseoli plasmids. J Bacteriol 169, 2828-2834.

Mercado-Blanco, J. \& Olivares, J. (1993). Stability and transmissibility of the cryptic plasmids of Rbizobium meliloti GR4. Arch Microbiol 160, 477-485.

Mozo, T., Cabrera, E. \& Ruiz-Arguleso, T. (1990). Isolation of the replication DNA region from a Rbizobium plasmid and examination of its potential as a replicon for Rhizobiaceae cloning vectors. Plasmid 23, 201-215.

Murillo, J. \& Keen, N. T. (1994). Two native plasmids of Pseudomonas syringae pathovar tomato strain P'T23 share a large amount of repeated DNA including replication sequences. Mol Microbiol 12, 941-950.

Nishiguchi, R., Takanami, M. \& Oka, A. (1987). Characterisation and sequence determination of the hairy-root inducing plasmid pRiA4b. Mol Gen Genet 206, 1-8.

Novick, R. P. (1987). Plasmid incompatibility. Microbiol Rev 51, 381-395.

Saitou, N. \& Nei, M. (1987). The neighbour-joining method: a new method for reconstructing phylogenetic trees. Mol Biol Evol 4, 406-425.

Sambrook, J., Fritsch, E. F. \& Maniatis, T. (1989). Molecular Cloning: a Laboratory Manual, 2nd edn. Cold Spring Harbor, NY: Cold Spring Harbor Laboratory.

O'Connell, M. P., Hynes, M. F. \& Puehler, A. (1987). Incompatibility between a Rhizobium Sym plasmid and an Ri plasmid of Agrobacterium. Plasmid 18, 156-163. 
Tabata, S., Hookyaas, P. J. J. \& Oka, A. (1989). Sequence determination and characterisation of the replicator region in the tumor-inducing plasmid pTiB6S3. J Bacteriol 171, 1665-1672.

Turner, S. L. \& Young, J. P. W. (1995). The replicator region of the Rhizobium leguminosarum cryptic plasmid pRL8JI. FEMS Microbiol Lett 133, 53-58.

Velázquez, E., Mateos, P. F., Pedrero, P., Dazzo, F. B. \& Martínez-

Molina, E. (1995). Attenuation of symbiotic effectiveness by
Rhizobium meliloti SAF22 related to the presence of a cryptic plasmid. Appl Environ Microbiol 61, 2033-2036.

Williams, D. R. \& Thomas, C. M. (1992). Active partitioning of bacterial plasmids. J Gen Microbiol 138, 1-16.

Received 10 November 1995; revised 15 February 1996; accepted 29 February 1996. 